\title{
Users' Perceptions of Shopping Activities in the Historic City of Malacca
}

\author{
Wan Hashimah Wan Ismail \\ Department of Architecture, Faculty of Built Environment, \\ Universiti Teknologi Malaysia \\ wshimah@yahoo.com
}

\begin{abstract}
The intent of this paper is to discuss the survival of the shop houses in the historic city of Malacca based on the research on the perceptions of the users, site observation and available documents. The findings of the research suggested that the shop houses were the most visited places. The users had both positive and negative perceptions on the shop houses in terms of comfort, circulation and other aspects that relate to shopping activities. The information can be used as a guide to ensure the continuous use of the shop houses as the setting for current and future activities.
\end{abstract}

Keywords: User. shop houses. perception. Heritage

eISSN 2514-751X @ 2017 The Authors. Published for AMER ABRA by e-International Publishing House, Ltd., UK.. This is an open access article under the CC BY-NC-ND license (http://creativecommons.org/licenses/by-ncnd/4.0/). Peer-review under responsibility of AMER (Association of Malaysian Environment-Behaviour Researchers), ABRA (Association of Behavioural Researchers on Asians) and CE-Bs (Centre for EnvironmentBehaviour Studies), Faculty of Architecture, Planning \& Surveying, Universiti Teknologi MARA, Malaysia.

https://doi.org/10.21834/aje-bs.v2i3.202 


\subsection{Introduction}

The survival of heritage buildings in the historic city of Malacca is vital to ensure the continuance of Malacca as a UNESCO World Heritage Site. The speciality of the area is the existence of many heritage buildings and living cultural heritage. The buildings found in the area include both the public and private buildings built during the colonisation of the European powers (1411-1957). Even though the private buildings, particularly the shop houses, dominate in terms of quantity, they are most vulnerable with regards to survival. The shop houses in this case are the premises built before 1948 and at some stages of time consist of the shop at the ground floor and the accommodation on the upper level. This paper is part of a larger research (Wan Hashimah, 2009) that investigates the users' perceptions on the heritage value of the shop houses and involves both categories of users; namely the static and mobile users. It includes the methods used to examine the users' perceptions of the heritage value of the shop houses, and the reasons behind their perceptions. Out of the two categories of users, only the mobile users are focused in this paper. The findings are discussed with some implications on the survival of the shop houses. Some recommendations and suggestions on related subject conclude this paper.

\section{Research Background}

\subsection{The issue}

Consciousness with regards to conservation heritage buildings is still a new phenomenon in Malaysia. The first public outcry was in 1983 in an attempt to save an old building that housed Malaysian Architects Association (P.A.M.). Despite some efforts by conservation enthusiasts, demolition and unsympathetic changes to original buildings and historic urban fabric still continue. It is also common to find new buildings and new façades sandwiched in between the rows of the shop houses in historic centres in Malaysia. The historic centres that still retain it historical character are basically found only in Penang and Malacca. Many of the shop houses in the other historic towns have been replaced with new buildings. Yet, three of the shop houses within the core area of the historic city of Malacca were destroyed in 2002.

It was only about five years ago that Malaysia proclaimed its own heritage act, known as National Heritage Act 2005 (Act 645). However, this Act covers all aspects of heritage and its effectiveness in saving heritage buildings is questionable. The demolition of the 77year-old Bok House at the end of 2006 signalled that more historical buildings will be reduced to rubble if the Act is not amended.

From the exploratory survey of several historic centres it was found that many of the shop houses had been replaced with new buildings and some of those that survived were in dilapidated state. Thus, it is assumed that the practice of conservation of the shop houses in Malaysia is not effective. This situation may be caused by the way the shop houses are valued. It was argued by some theorists such as Jokilehto (2002), Fielden (1982) and 
Harvey (1972) that the survival of the old buildings depends very much on how they are valued. While the controllers that include the state government and the local authority as well as some professionals recognise the importance of the old buildings within the area, it is uncertain that the users feel likewise. The issue here is thus, how the users perceive the heritage value of the shop houses in the historic centres.

\subsection{The case study area}

The area chosen for the case study is the conservation area listed as UNESCO World Heritage site and defined by the Historic Malacca City Council (MBMB) as the 'Core Zone'. The area covers part of the settlement quarters, commercial area and civic zone (Figure1). Historically, the area on the eastern side of the core zone was developed by the Portuguese ( $16^{\text {th }}$ century). The settlement quarters on the western side was built by the Dutch (1 $17^{\text {th }}$ century) to house the officers. It was during the British occupation that some of the settlement quarters were transformed to shop houses (Lim and Fernando, 2006).

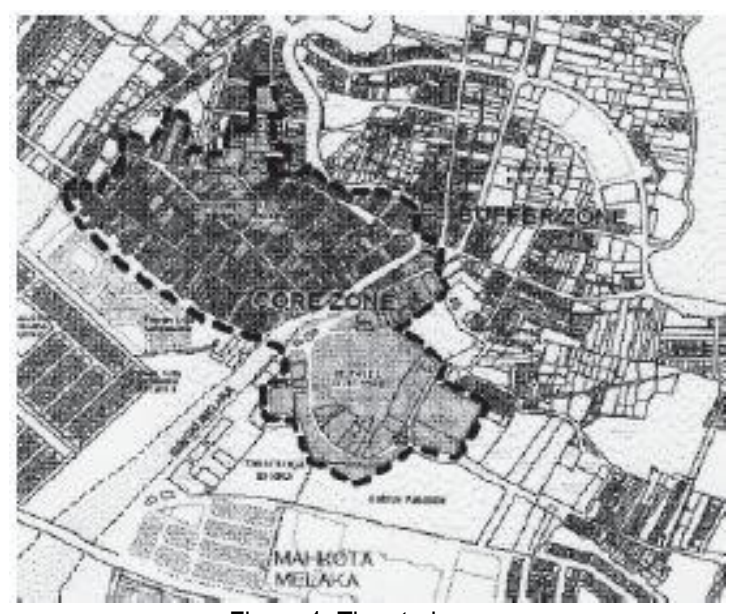

Figure 1: The study area

Source: (MBMB, 2008)

\subsection{The users of the area}

Based on site observations and with reference to previous research (Dolbani, 2000; Norsidah, 2008, 2010), the users of the streets in the study area can be broadly clustered into two distinct groups, namely the static and mobile users. The static users are those who have constant (daily) engagement with the study area such as shop owners, shopkeepers, vendors, office workers and residents. The mobile users on the other hand, are those who are not dependent on daily engagement with the study area. The mobile users or visitors of the historic centre were included because as highlighted by Krupat (1985) and Tuan (1974), 
visitors possessed more distinctive viewpoints and images compared to any resident sub group. Thus, both categories of users were included in the larger research. This paper, however, focuses on shopping activities that involves the mobile users only.

\subsection{Methodology}

Users' perceptions towards the shop houses is influenced by many factors and can only be proven by more than a single evidence and inter-related aspects. The research employed a mixed method, namely quatitative and qualitative methods, as recommended by Creswell (1994) and Bryman (2001), among others. The quantitative method employs exploratory, pilot survey and main survey in collecting data. This model allows for each technique to maximise strength and minimise weakness of each design. In this case, the quantitative method using questionnaire survey technique is counter checked with the qualitative method using in-depth interview, field observation and content analysis.

For the main survey 330 users were employed as respondents, based on 5.5\% sampling error at $95 \%$ confidence level according to de Vaus (2003). To ensure equal representation of each category of users, the total number of respondents required (330) was divided into two equal half. Thus, each category of users (static and mobile users) required 330 divided by 2 equal 165 respondents. As mentioned earlier, this paper concerns only the perceptions of the mobile users.

In collecting data from the mobile users, this study has employed probability sampling using 'time interval' techniques as suggested by Creswell (1994) and used by Norsidah (2008) and Wan Mohd Zakri (2008). In this case, a 3 hour period was set for the first set of surveys. Then, an interval of 40 minutes was set before the next set of surveys was carried out. The mobile respondents were selected at random from those who were in the study area at the time of the survey and were willing to participate. The time allocated for each respondent to complete the survey was between 15 to 20 minutes.

The data collected from the main survey was processed through sorting, coding, categorisation and cross-tabulation using statistical package for science social (SPSS). After analysis, the in-depth interview was carried out further clarify certain patterns or issues in the feedback from the respondents and to confirm some of the responses. In this case 20 mobile users of the study area participated. The data collected was then converged through triangulation method. This method is used based on the assumption that biasness will be neutralised when used in conjunction with other data sources, investigators and methods as recommended by Jick (1979) and Creswell (1994).

\subsection{Results and Discussions}




\subsection{Perceptions on the shop houses as components of the historic city of Malacca}

As observed on the site and through literature review (MBMB, 2003), the components of the built structures in the area include both private and public buildings according to building use. Private buildings include the row houses (residential) and the shop houses (commercial). The major land use in the Historic city of Malacca is commercial (520 units, $36.54 \%$ ) followed by residential (300 units, $20.63 \%)$. The components of public buildings (museum, religious and historical monument) add up to 36 units $(2.47 \%)$.

The findings of the MBMB survey (2003) however, were not reflective in the free recall exercise (part of the main survey) of old buildings in the area. It was found that the majority $(87.7 \%)$ of the mobile users chose the public buildings, in particular, the well-known buildings (Fig. 2). This means that even though the percentage of the public buildings is very few in the area the majority of the mobile users preferred them rather than the private buildings.

The finding supports the arguments by Serageldin (2000) that there is a clear distinction between landmarks and non-monumental buildings. Even though the non-monumental buildings or private buildings provide the setting for monuments, there is an apparent lack of appreciation in the architectural heritage as a determinant of cultural identity in societies. Traditionally, only the monumental buildings were perceived as cultural symbol.

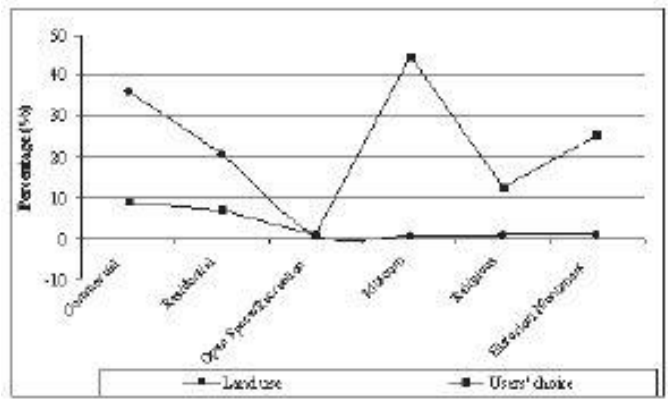

Figure 2: Percentage of land use and users' choice of old buildings Sources: (MBMB, 2003) and (Fieldwork, 2005)

The choice of old buildings among the users was in contrast to the most visited buildings in the historic city of Malacca (Table 1). More than half $(55.15 \%)$ of the mobile users chose the shops houses either to shop $(43.03 \%)$ or to eat $(12.12 \%)$. Through observation it was found that the majority of the users in the western side of the study area actually went to the shops. Presumably, the bulk of mobile users are expected to visit the area as long as the shops within the area survive. Only a minority went to the other old buildings such as the temple and mosque within the study area. 
Indication of the findings is that even though the shop houses were most visited by the mobile users and lived in by some of the static users, the building type was not perceived as important old buildings by majority of the users. This is in line with the statement by Heritage of Malaysia Trust (2004) that there is a lack of recognition for the shop houses.

\begin{tabular}{lcc}
\multicolumn{3}{c}{ Table 1: Most visited building } \\
\hline Building Types & $\begin{array}{c}\text { Number of } \\
\text { Mobile Users }\end{array}$ & $\begin{array}{c}\text { Percentage of } \\
\text { Mobile Users }\end{array}$ \\
\hline Shop house (conmercia) & 71 & 43.03 \\
Restaurant & 20 & 12.12 \\
Hotel & 2 & 1.21 \\
Bank & 3 & 1.82 \\
Mosque & 8 & 4.85 \\
Temple (Indian) & 7 & 4.24 \\
Ternple (Chinese) & 24 & 14.55 \\
Row houses (residentia) & 2 & 1.21 \\
Others & 28 & 16.97 \\
Total & 165 & 100.0 \\
\hline
\end{tabular}

Source: (Fieldwork, 2005)

\subsection{Perceptions on comfort in shopping in the interior of the shop houses}

Through observation, it was noted that shopping activities at the shop houses in the study area took place both indoor and outdoor. The outdoor areas were basically along the verandah-way which served as circulation area for the users and display area for merchandise.

It was noted earlier that the shops was the most visited building type in the historic city of Malacca. This relates to the outcome of the main survey whereby the majority $(68.48 \%)$ of the mobile users perceived that the shop spaces were comfortable for shopping activities (Table 2). This finding was further confirmed in the in-depth interview whereby three quarter $(75.0 \%)$ of the mobile users perceived the interior of the shop houses to be comfortable for shopping activities.

Table 2: Shop spaces comfortable for shopping activities

\begin{tabular}{lcc}
\hline $\begin{array}{l}\text { Comfort In Shopping } \\
\text { Activities (Interior) }\end{array}$ & Number & Percentage \\
\hline Yes & 113 & 68.48 \\
No & 52 & 31.52 \\
Total & 165 & 100.00 \\
\hline
\end{tabular}

Source: (Fieldwork, 2005)

The users related to several aspects that make the interior perceived to be comfortable for shopping activities and similar reasons were given in both fieldwork and in-depth interview. The most important one was the suitable arrangements of the merchandise $(35.40 \%$ of users in fieldwork and $40 \%$ of users in in-depth interview). Through observation 
it was found that many of the shops actually sold small items, particularly souvenirs. A neat arrangement of the merchandise helped to ensure the feeling of vastness in the shop houses even though the actual width was quite narrow.

The other reasons included merchandise availability $(23.89 \%$ of users in fieldwork and $20.0 \%$ of users in in-depth interview) and comfort in circulation due the layout of the shops (23.89\% of users in fieldwork and $20.0 \%$ of users in in-depth interview). It is a common feature in the old towns such as the historic city of Malacca that the shop houses are arranged in rows lining the street (Fig. 3).

The indication of the result of the main survey was that about one third of the users $(31.52 \%)$ perceived the shop spaces to be uncomfortable for shopping activities. This finding was confirmed by the outcome of the in-depth interview whereby one quarter $(25.0 \%)$ of the users perceived the interior of the shop houses to be uncomfortable. The main reasons given by the users relate to the narrowness of the shops and the overcrowding of merchandise arrangement within the shops $(38.46 \%$ of users in fieldwork and $60.0 \%$ of users in in-depth interview). Through observation, it was found that some of the shops, particularly in Jonker Street, were too crowded with merchandise as a result of trying to place as much items as possible within the shop space.

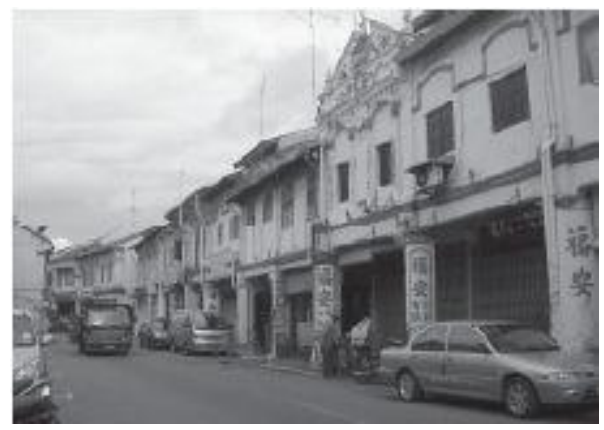

Figure 3: Shop houses arranged in rows

\subsection{Perceptions on shopping in the outdoor area of the shop houses}

The flow over of business to verandah-way is practiced since the old times. It should be noted that the shop houses in Malacca do not have five-footway (kaki lima) as normally found in front of the shop houses in other major town in Malaysia. There is only a small verandah about 3 feet wide as part of the porch of the rowhouse before the conversion to become the shop house. Through observation, it is found that the direct linkage from one old shop house to the other through a five-footway, a character found in other shop houses elsewhere, is not evident in Malacca. Many of the verandah-way along Jalan Tun Tan Cheng Lock and Jonker Street are blocked. 
The users of the study area perceived comfort in shopping to have some connections to the outdoor area of the shop houses. That included both the verandah-way and the adjacent streets. However, the majority of the respondents (65.0\%) in the in-depth interview considered the verandah-way in front of the shop houses to be uncomfortable and unsafe for shopping (Table 3). The main reason given was due to the heavy traffic in the area (53.85\% of uncomfortable mobile users). The other reasons were the combination of both poor arrangement and over-crowding of merchandise that resulted in poor circulation along the verandah-way that continue to the interior of the shops.

Table 3: Comfort in shopping in the exterior

\begin{tabular}{lcc}
\hline Comfort in Shopping (Exterior) & Number & Percentage \\
\hline Yes & 7 & 35 \\
No & 13 & 65 \\
Total & 20 & 100.0 \\
\hline
\end{tabular}

Source: In-depth interview (2006)

The findings support the idea of pushing the car away from the main core of the historic city as in the case of historic cities, such as Petaling Street in Kuala Lumpur and Clarke Street in Singapore. In those places cars do not seem to be an essential element in inviting shoppers to the area. Shoppers were drawn to the area even though there is restriction in both centres.

\subsection{Conclusion}

A major contribution to historical value is the continuous use of a place the way it was designed and this is achieved through direct association with the heritage buildings. It was found that the mobile users were associated with the historic city of Malacca mainly due to the diverse choice of activities in the area and the shop houses were the most visited building. However, the findings of the research suggest that the shop houses lack in recognition among the visitors to the historic city centre. This suggests that the earlier arguments of an apparent lack of appreciation on non-monumental buildings also apply to the perceptions of the $21^{\text {st }}$ century users of the historic city of Malacca. It was also found that the users had both positive and negative perceptions on the shop houses in terms of comfort, circulation and other aspects that relate to shopping activities. The shop houses were not fully perceived as comfortable spaces for shopping activities since one third of them perceived otherwise. It was found that the feeling of discomfort in shopping had some connections with heavy traffic, the narrowness of the interior made worst by the overcrowding of merchandise and crowded verandah-way. Even though some efforts were already done by the local authority to upgrade the area, it was considered not good enough by half of the users. These reasons may affect the cessation of the use of the shop houses 
and diminish its associational value. Thus, the shop houses and the adjacent areas need to be improved to ensure the continuous use and their survival. It has been frequently suggested by scholars that studies of environmental perception can act as an important information base to achieve quality environment. In this case the information can be used as a guide to ensure the continuous use of the shops houses as the setting for current and future activities and subsequently the retention of the area as a UNESCO World Heritage Site.

\section{Acknowledgement}

This study was made possible by the continuous support from Universiti Teknologi Malaysia.

\section{References}

Bryman, A. (2001). Social Research Methods. Oxford: Oxford University Press.

Creswell, J. W. (1994). Research Design: Qualitativ and Quantitative Approaches. London:

Sage Publications, Inc.

Creswell, J. W. (1994). Research Design: Qualitative and Quantitative Approaches. London: Sage Publications, Inc

De Vaus, D. A. (2003). Research Design in Social Research. (3rd. ed.) London: Sage Publications.

Feilden, B. M. (1982). Conservation of Historic Buildings. London: Butterworth Scientific

Jick, T.D. (1979). Mixing Qualitative and Quantitative Methods: Triangulation in Action. Administrative Science Quarterly. 24.602

Jokilehto, J. (2002). A History of Architectural Conservation. (3rd. ed.). Oxford: Butterworth Heinemann.

Krupat, E. (1985). People in Cities: The Urban Environment and its Effects. New York: Cambridge University Press.

Lim, Huck Chin and Fernando, J. (2006). Malacca: Voices from the Street. Malaysia: Lim Huck Chin.

Majlis Perbandaran Melaka Bandaraya Bersejarah (MBMB) (2003). The Study on the Improvement and Conservation of Historical Urban Environment in the Historical City of Melaka. Melaka.

Norsidah Ujang (2008). Place Attachment Towards Shopping District in Kuala Lumpur City Centre. Universiti Putra Malaysia: Ph.D Thesis in Architecture.

Serageldin, M. (2000). Preserving the Historic Urban Fabric in a Context of Fast-Paced 
Wan Ismail, W.H., / Asian Journal of Environmen-Behaviour Studies, ajE-Bs, 2(3), Apr./Jun. 2017 (p.99-108)

Change. In Avrami, E., Mason, R. and de la Tore, M.(Ed.).Values and Heritage Conservation. (pp. 51-58). Los Angeles: the Getty Conservation Institute.

Tuan, Yi-Fu (1974). Topophilia: A Study of Environmental Perception, Attitudes, and Values. New Jersey: Prentice-Hall Inc.

Wan Hashimah Wan Ismail (2009). Users' Perceptions on The Heritage Value of the Shop houses in The Historic City of Malacca. Universiti Teknologi Malaysia: Ph.D Thesis in Architecture. 